\title{
Concentration of heavy metals in two fish species (Cynoscion regalis and Pomatomus saltatrix) from an oil drilling area in Western Coast of Ghana and public health risk assessment
}

\author{
Francis Ofosu \\ Institute for Environment and Sanitation Studies (IESS), College of Basic and Applied Sciences, \\ University of Ghana, Legon, Accra \\ Benedicta Y. Fosu-Mensah* (iD \\ Institute for Environment and Sanitation Studies (IESS), College of Basic and Applied Sciences, \\ University of Ghana, Legon Accra

\section{Daniel Nukpezah} \\ Institute for Environment and Sanitation Studies (IESS), College of Basic and Applied Sciences, \\ University of Ghana, Legon Accra \\ Michael Mensah \\ Department of Business Administration, University of Professional Studies, Accra (UPSA), \\ Ghana \\ *Corresponding author: Email: yayramensah@staff.ug.edu.gh
}

\section{Article Info}

https://doi.org/10.31018/ jans.v13i2.2640

Received: March 28, 2021

Revised: May 9, 2021

Accepted: May 18, 2021

\section{How to Cite}

Ofosu, F. et al. (2021). Concentration of heavy metals in two fish species (Cynoscion regalis and Pomatomus saltatrix) from an oil drilling area in Western Coast of Ghana and public health risk assessment. Journal of Applied and Natural Science, 13(2), 520 - 529. https://doi.org/10.31018/jans.v13i2.2640

\begin{abstract}
This study assessed heavy metals (Lead $(\mathrm{Pb})$, Nickel $(\mathrm{Ni})$, Iron ( $\mathrm{Fe})$, Chromium ( $\mathrm{Cr}$ ), and Cadmium (Cd)) concentration in water (from borehole, hand-dug well and the sea) and fish (Cynoscion regalis and Pomatomus saltatrix species) and possible health risk exposure by the consumption of these fishes. A total of 18 samples of water and samples of two species of fish (C. regalis and $P$. saltatrix) were collected from Jomoro, Ellembelle and Ahanta West District and analyzed for the concentration of $\mathrm{Pb}, \mathrm{Ni}$, $\mathrm{Fe}, \mathrm{Cr}$, and $\mathrm{Cd}$ using Atomic Absorption Spectrometer (AAS). Results revealed appreciable concentrations of $\mathrm{Pb}, \mathrm{Ni}$, and $\mathrm{Fe}$ in the fish muscle and $\mathrm{Ni}, \mathrm{Cr}$, and $\mathrm{Fe}$ in water. Cadmium and $\mathrm{Cr}$ were not detected in the fish samples. Heavy metals in fish increased in the order $\mathrm{Pb}<\mathrm{Ni}<\mathrm{Fe}$. The Estimated Daily Intake of fish value for adult ranged $1.88 \times 10^{-3}$ to $2.03 \times 10^{-1}$ (mg/kg bw/ day), however, those for children were $4.40 \times 10^{-3}$ to $4.74 \times 10^{-1}(\mathrm{mg} / \mathrm{kg}$ bw/day). For health risk assessment, the Total Targeted Hazard Quotient for adults was $<1$; however, those for children were $>1$ for $C$. regalis but less than $1(<1)$ for $P$. saltatrix meaning children who consume $C$. regalis are exposed to health risk in their life time. The results confirmed that contaminated environments could result in bioaccumulation of metal pollutants in fish's muscle, which poses a health risk to humans when consumed. Awareness and education of the general public on the threshold of heavy metals in fish and water are crucial to safeguard against health risks.
\end{abstract}

Keywords: Cynoscion regalis, Heavy metals, Health risk assessment, Oil, Pomatomus saltatrix, Water

\section{INTRODUCTION}

Heavy metals remain one of the important classes of environmental pollutants due to their toxicity and persistence in the environment. Though heavy metals occur as natural elements, studies relate their increasing concentrations and pollution to point source anthropogenic and industrial activities, including oil and gas extraction (Noor-ul and Tauseef 2015; Faz and Acosta 2017; Demková et al., 2017 and Kinuthia et al., 2020). Analy- sis of crude oil shows relatively high concentrations of heavy metals such as $\mathrm{Cu}, \mathrm{Hg}, \mathrm{Zn}, \mathrm{Pb}$ and Fe (Kadafa, 2012). During oil and gas production, hydrocarbon reservoirs release a by-product (Produced Water) which is either disposed-off into the ocean or may be re-injected into the wells to promote oil recovery (lgwe et al., 2013). The inability to eliminate heavy metals through natural processes aggravates the situation. This results in heavy metals moving from one compartment of the environment (aquatic) to another (terrestrial and biota) 
(Katavut et al., 2010) with detrimental impacts like bioaccumulation. Exposure to high concentrations of $\mathrm{Pb}$, $\mathrm{Ni}$ and $\mathrm{Cr}$ are reported to cause central nervous system disorders, cardiovascular diseases, kidney failure, lung fibrosis, fertility problems, sinus node dysfunction and atrioventricular conduction disturbances, liver necrosis, myocardial dysfunction and cardiogenic shock among others.

In adjoining drilling communities, heavy metals contamination in water bodies might result from the indiscriminate discharge of drilling effluents and accidental leakages through iron pipes, thus contributing directly to heavy metals concentrations in the aquatic environment (Owamah 2013 and Ghaderpoori et al., 2018). Pollution of such nature has direct and indirect devastating effects on biological, physical and chemical characteristics of the environment (Abdel-Shafy and Mansour, 2016) with biodiversity and ecosystem services loss and, threats to public health (Ubiogoro and Adeyemo, 2017). It is established for example that, the presence of oil in water results in oxygen deficit thus affecting the rate of fish metabolism and decreases their ability to withstand organic and inorganic poisons (Lloyd, 1992). Other impacts include disruptions in response patterns associated with stimulation, depression, movement, coordination, and breathing, leading to the death of organisms (Demeke and Tassew 2016).

In Ghana, the oil and gas industry became prominent in 1970 along the Western Coast off the Cape Three Points although exploratory efforts began in 1896 (GNPC, 2009). A rapid development in 2010 paved the way for pumping to start from wells in the Deepwater Tano and the West Cape Three Points blocks making Ghana an important producer in West Africa after Nigeria, "pumping upwards of 500,000 barrels per day" (Global Muckraking, 2012). The heightened oil production and related activities in the deep waters of Ghana have raised concerns regarding the potential pollution of the aquatic system and its implications for the communities in the activity zone who are largely involved in fisheries and agriculture-related livelihoods.

To effectively track and manage the impact of oil and gas exploration on the communities along the coast, it is crucial to understand the dynamics and spatial distribution of pollutants such as heavy metals concentration in the environment. However, there is little information on the concentration of heavy metals in water and fish in communities along the oil and gas drilling areas of Cape Three Points in Western Ghana. Preliminary analysis of polycyclic aromatic hydrocarbons (PAHs) concentrations in water showed results below the detection limit. This research aims at assessing the concentrations of heavy metals in water and fish and the public health risks associated with the consumption of fish from the western coast of Ghana.

\section{MATERIALS AND METHODS}

\section{Study area}

The study was conducted in three districts along the western coast of Ghana near the jubilee oil field in the Western Region of Ghana. Six communities were randomly selected along the coastline within $60 \mathrm{~km}$ from where oil and gas activities occur. The chosen communities were Half Assini and Kabenlasuazo in Jomoro District, Atuabo and Eikwe in Ellembelle District and Cape Three Points and Princess Town in Ahanta West District (Fig. 1). In each community, two sites were identified purposively for sampling. The selection criterion was based on distance $(60 \mathrm{~km})$ to the area of oil and gas exploration. The study area is located between latitude $4^{\circ} .45^{\prime} \mathrm{N}-5^{\circ} .02^{\prime} \mathrm{N}$ and longitude $2^{\circ} .04^{\prime} \mathrm{W}-2^{\circ} .53^{\prime} \mathrm{W}$ and is in close proximity to Ghana's major offshore oil and gas exploration and production sites. The sandy shores of the Cape Three Points area serves as nesting grounds for sea turtles and habitats for several species, including the ghost crab, isopods, polychaetes, bivalves and gastropods (Armah et al., 2004).

\section{Water sampling and physico-chemical analysis}

Water samples were collected from 6 hand-dug wells, 6 boreholes (drinking water sources) and sea water (six samples) located within the study area. Wells and boreholes were selected based on the distance to gas and oil drilling area. The control samples were, however, collected from areas where no oil and gas activities take place (about $13.6 \mathrm{~km}$ away from the experimental site). Two water samples were collected from each category of water sources from each community within the study area. Similarly, two samples were collected from the control. A water sampler was used to collect water samples into $1.5 \mathrm{~L}$ and $500 \mathrm{~mL}$ pre-cleaned polyethylene sample bottles with caps for heavy metals and physico-chemical analysis, respectively. The sampling bottles were rinsed with the water source before taking the water samples. The samples were well labelled and transported to the Ecological Laboratory (ECOLAB) of University of Ghana, Legon, on ice in clean ice chests and stored in the refrigerator at $4{ }^{\circ} \mathrm{C}$ until they were analysed for physico-chemical parameters and heavy metals. The physico-chemical parameters analysed included: $\mathrm{pH}$, electrical conductivity, biological oxygen demand (BOD), dissolved oxygen (DO), dissolved solids (TDS), turbidity and salinity. All the analytical procedures used in the physico-chemical analysis of the water samples were done according to the standard method of water analysis (Rodier et al., 2009).

\section{Fish samples collection}

Samples of the most common fish species (Pomatomus saltatrix (Blue fish) and Cynoscion regalis 


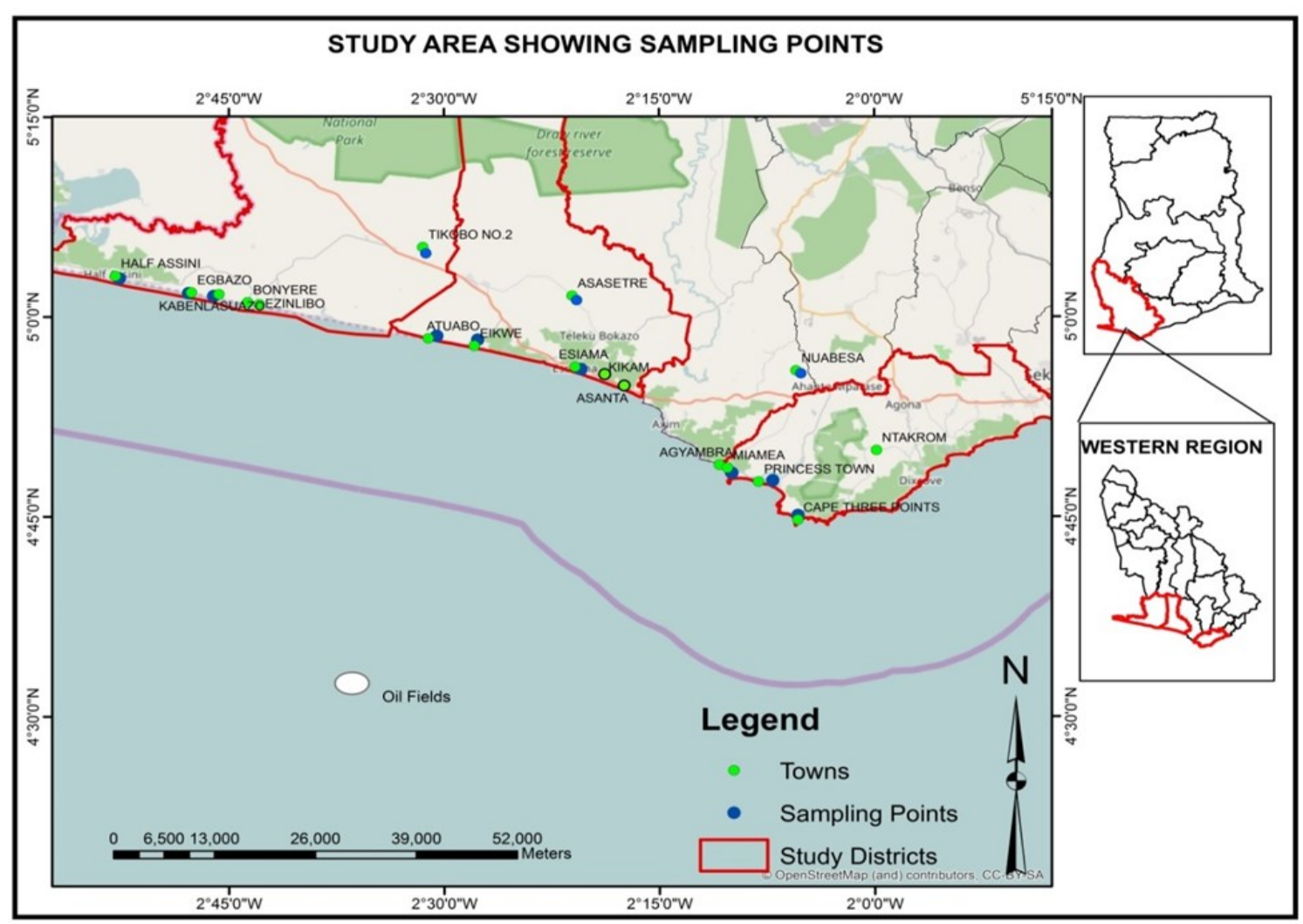

Fig. 1. Map of the study area.

(Weakfish) were obtained from local commercial fishermen in March 2017. Samples for the control were collected outside the study area. The fish samples were well labelled and kept in an ice chest at $4 \circ \mathrm{C}$ to avoid microbial activity and were transported to the Ecological Laboratory of the University of Ghana for analysis of heavy metals.

\section{Determination of heavy metals in water and fish samples}

Standard procedures were followed for the quantitative determination of heavy metals in all samples. Heavy metal concentrations in the water and fish (Iron (Fe), Lead $(\mathrm{Pb})$, Cadmium (Cd), Nickel (Ni) and Chromium (Cr)) samples were determined using direct flame Atomic Absorption Spectrometry (AAS) of model PinAAcle 900T, Boston, MA, USA by using different Cathode lamps.

Concentrations of heavy metals in water samples were determined using a specific wavelength for each metal. Average values of three replicates were taken for each determination. An appropriate drift blank was taken before the analysis of samples. The working wavelength for the heavy metals was $248.3 \mathrm{~nm}$ for Fe, 217 $\mathrm{nm}$ for $\mathrm{Pb}, 228.8 \mathrm{~nm}$ for $\mathrm{Cd}, 357.9 \mathrm{~nm}$ for $\mathrm{Cr}$ and 232 $\mathrm{nm}$ for $\mathrm{Ni}$.

Each of the fish samples was dissected using stainless steel scalpels, forceps and scissors in a dissecting tray to separate muscles and gills. The muscles and gills were then dried in labelled pre-washed crucibles at 70 ${ }^{\circ} \mathrm{C}$ for $24 \mathrm{~h}$ in an oven. Each dried sample was then pulverised, homogenized with a porcelain mortar and pestle and stored in labelled pre-treated specimen bottles, then transferred to preweighed crucibles and dried again oven until a constant weight was obtained. One gram of the dry sample was placed in a Teflon beaker and digested with $10 \mathrm{~mL}$ analytical grade nitric acid $\left(\mathrm{HNO}_{3}\right)$ and hydrogen peroxide $\left(\mathrm{H}_{2} \mathrm{O}_{2}\right)(1: 1)$ on a hot plate at $100{ }^{\circ} \mathrm{C}$ to near dryness when a clear solution was obtained. The solution was then diluted up to 25 $\mathrm{mL}$ with distilled water, following which the concentrations of trace elements in each sample were determined using atomic absorption spectrophotometer. Blank experiments were run to check for background contaminants by the reagents and apparatus used. The values obtained from running blank experiments were subtracted from the analyte values as applicable. The Atomic Absorption Spectrophotometer (AAS) was precalibrated. The calibration was done with 10, 8, 6, 4, 2 and 0 ppm solution of the metals obtained by serial dilution of 1000 ppm of the stock standard metal solution. Analysis of each sample was carried out in triplicate and results expressed in $\mathrm{mg} / \mathrm{kg}$ (ppm). Data obtained was analysed and the results were expressed as mean \pm Standard Deviation.

The heavy metals analysed are the most predominant metals in the region where the study took place (Appiah-Opong et al., 2021). 
Determination of physico-chemical parameters of water

Water analyses were carried out using the standard procedures outlined in the standard methods for the examination of water (Rodier et al., 2009). Physical parameters such as total dissolved solids (TDS) and turbidity were determined in addition to chemical parameters such as $\mathrm{pH}$, Electrical Conductivity, BOD, DO and Salinity. Turbidity was measured using turbidimeter (Model HACH 2100P) and total dissolved solids (TDS) measured with a portable digital TDS meter (Model HI 99301) whilst salinity was measured using a hand-held refractometer. The physico-chemical parameters, including $\mathrm{pH}$, Organic Carbon (OC), Conductivity and Cation Exchange Capacity (CEC) of soil were analysed using $\mathrm{HACH}$ model multi-probe meter $(U-50$ series).

\section{Public health risk assessment of heavy metals in fish}

Researchers have used different health risk estimation methods to evaluate the risk that consumption of contaminated fish poses to humans (KwaansaAnsah et al., 2019; Rai et al., 2019; Griboff et al., 2017 and $\mathrm{Yi}$ et al., 2017). In order to identify the number of pollutants consumed on a daily basis, the Estimated Daily Intake (EDI) was used (KwaansaAnsah et al., 2019 and Vrhovnik et al., 2013). Similarly, Vrhovnik et al. (2013) reported that the EDI of potentially toxic elements (PTE) is directly proportional to PTE concentrations in the food consumed daily.

\section{Data analysis}

The means, maximum and minimum ranges for various parameters were generated from data using Statistical Package for the Social Sciences (SPSS) software version 22.0. Analysis of variance (ANOVA) at 95\% confidence level ( $5 \%$ level of significance) was used to test for the significant differences in concentrations among the various water sources as well as fish species. The Estimated Daily Intake (EDI), hazard quotient (HQ) and Target Hazard Quotients (THQ) were determined for the fish. Karl Pearson's Product Moment Correlation analysis was carried out to establish the strength and direction of the relationship between the parameters of the water samples and soil samples. A correlation coefficient of $p<0.5$ was deemed statistically significant.

The EDI of heavy metals for adults was calculated as follows (Rai et al., 2019; Kwaansa-Ansah et al., 2019; and Vrhovnik et al., 2013):

$\mathrm{EDI}=\frac{C x C \text { cons }}{B w}$

where $\mathrm{C}$ is the concentration of heavy metals in fish ( $\mathrm{mg} / \mathrm{kg}$ wet weight), $\mathrm{C}_{\text {cons }}$ is the national average daily consumption of fish (71 g/day Bw), and Bw represents the body weight $($ Adult $=70 \mathrm{~kg}$; Chn $(1-11 \mathrm{yrs})=30 \mathrm{~kg})$.

$$
\begin{aligned}
& \mathrm{HQ}=\frac{E D I}{R f D} \\
& T H Q=\frac{\text { EF } \times \text { ED } \times \text { FIR } \times \mathrm{C}}{\text { RfD } \times \text { W } \times \text { ATn }} \times 10^{-3}
\end{aligned}
$$

Where:

$E F=$ the exposure frequency (365 days/year)

$E D=$ the exposure duration (64 years (WHO, 2020)) equivalent to the average lifetime in

Ghana;

FIR = the food ingestion rate (in grams per person per day); Ghana's average annual per capita consumption of fish is at $26 \mathrm{~kg}$ (and the daily ingestion works out to $71 \mathrm{~g} /$ day) (USDA, 2019).

$\mathrm{C}=$ the metal concentration in food $(\mathrm{mg} / \mathrm{g})$;

$\mathrm{RfD}=$ the oral reference dose (in milligram per kilogram per day);

$\mathrm{W}=$ the average body weight $(71 \mathrm{~kg}$ for adults (Shirazu et al., 2017), and

ATn $=$ the average exposure time for non-carcinogens (365 days/year i.e., number of exposure years, assuming 64 years in this study). It was assumed that cooking does not affect the toxicity of heavy metals in seafood.

\section{RESULTS AND DISCUSSION}

\section{Physico-chemical parameters of water}

A summary of the physico-chemical parameters of water is presented in Table 1. The mean $\mathrm{pH}$ values of water (main test seawater, hand-dug well and borehole water) sampled from the study area were generally higher than their controls. The $\mathrm{pH}$ values ranged from $\mathrm{a}$ minimum of $6.1 \pm 0.35$ (borehole main test) to a maximum of $7.6 \pm 0.24$ (sea main test). Analysis of variance (ANOVA) showed a significant difference $(p<0.05)$ in $\mathrm{pH}$ among the different water sources. Bonferroni pairwise multiple comparisons showed no significant difference $(p>0.05)$ between the main water sources and their controls. The results of $\mathrm{pH}$ values in all sources of water in this study were higher than those reported by Chiamsathit et al. (2020) in Thailand.

The mean conductivity of the water samples ranged from a minimum of $246.8 \pm 88.9 \mu \mathrm{S} / \mathrm{cm}$ (borehole) to a maximum of $4618.9 \pm 673.0 \mu \mathrm{S} / \mathrm{cm}$ (Seawater). Analysis of variance (ANOVA) showed a significant difference ( $p$ $<0.05$ ) among water sources. Bonferroni pair-wise multiple comparisons showed no significant difference $(p>$ 0.05 ) between the main water sources (borehole, handdug well and sea water) and their controls. The recorded conductivity value for water from hand-dug wells (main source) and the control samples exceeded the WHO recommended limit of $250 \mu \mathrm{S} / \mathrm{cm}$ for drinking water. The shallow nature of the wells might have allowed 
pollutants from the environment to enter the water. Oil and gas installations come with discharges such as produced water, process water, sewerage, sanitary and domestic waste, spills and leakages (EP Forum/ UNEP, 1997). The values reported in this study were lower than the values reported by Barmon et al. (2018) in water from Mokesh beel in Bangladesh except for values for sea water.

The BOD of water was generally higher in the main water sources than their controls. This suggests a relatively higher organic pollution of the main water source. Analysis of variance (ANOVA) of BOD revealed statistically significant differences $(p<0.05)$ among the different water sources. There was, however, no significant difference $(p>0.05)$ between the main test water sources and their controls.

The mean BOD values in the main water sources ranged from $4.14 \pm 0.48 \mathrm{mg} / \mathrm{L}$ (hand dug well) to $6.08 \pm 0.35 \mathrm{mg} / \mathrm{L}$ (borehole main source).

Generally, DO in the main water test was higher than the controls. The mean DO of the main (test) water samples ranged from a minimum of $8.29 \pm 0.72 \mathrm{mg} / \mathrm{L}$ (Hand-dug well) to a maximum of $10.37 \pm 0.31 \mathrm{mg} / \mathrm{L}$ (borehole). Analysis of variance (ANOVA) showed no significant difference $(p>0.05)$ among the different water sources. There was no significant difference $(p>$ $0.05)$ between the test water and their controls. Generally, a higher BOD in a sample translates into a lower DO. In Fishes, an average of $5 \mathrm{mg} / \mathrm{L}$ of dissolved oxygen (DO) is required for them to survive (Mallya, 2007). Thus, decreased DO levels may result in the death of fish and or stress of fishes and other organisms. Factors that affect DO levels in natural water include the presence of oxidisable substances, salinity, turbulence, temperature, and pressure (Demeke and Tassew 2016). DO values in this study were higher than the values (less than $6.0 \mathrm{mg} / \mathrm{l}$ ) reported by Barmon et al. (2018) in water from Mokesh beel in Bangladesh.

The results of water salinity recorded in the main test water were generally higher than their controls. However, there was no significant difference $(p>0.05)$ between the main water sources and their controls. The values of salinity in the main test water sources ranged from a minimum of $0.008 \pm 0.04 \mathrm{mg} / \mathrm{L}$ (borehole) to a maximum of $29.9 \pm 5.02 \mathrm{mg} / \mathrm{L}$ (sea water). Analysis of variance showed statistically significant differences $(p<$ 0.05 ) in salinity among the different water sources.

Similarly, the mean values recorded for TDS in the test water ranged from a minimum of $161.0 \pm 57.58 \mathrm{mg} / \mathrm{L}$ (borehole) to a maximum of $2766.7 \pm 400.67 \mathrm{mg} / \mathrm{L}$ (sea water). Analysis of variance showed a significant difference $(p<0.05)$ among the different water sources but no significant difference $(p>0.05)$ between the test water and their controls. Values near $600 \mathrm{mg} / \mathrm{L}$ are acceptable, whereas those greater than $1000 \mathrm{mg} / \mathrm{L}$ are unpalatable for drinking (Apau et al., 2014). The TDS for all sources of water were within WHO recommended guidelines $(1000 \mathrm{mg} / \mathrm{L}$ and $30,000 \mathrm{mg} / \mathrm{L})$ for drinking water and saline water, respectively. The results of TDS from all water sources in this study are similar to those reported by Amfo-Out et al. (2012) and Chiamsathit et al. (2020) at the Ga East Municipality of Ghana and Thailand, except for the sea water.

The results of turbidity of the test water samples ranged from a minimum of $0.64 \pm 0.11 \mathrm{NTU}$ (borehole) to a maximum of $12.1 \pm 3.15$ NTU (sea water). The turbidity of test water samples was higher than their controls. Analysis of variance showed statistically significant differences $(p<0.05)$ in turbidity among the different water sources but no significant difference $(p<0.05)$ was recorded between the test water and their control.

\section{Heavy metal concentration in water samples}

The mean concentration of Nickel in test water ranged from a minimum of $0.44 \mathrm{mg} / \mathrm{L}$ (hand-dug well) to a maximum of $0.77 \mathrm{mg} / \mathrm{L}$ (sea water) (Fig. 2). The value of Nickel in the main water sources was higher than their controls. Analysis of variance, however, showed no significant difference $(p>0.05)$ between the main test water and their respective controls.

The presence of $\mathrm{Cr}$ was recorded in the different sampled water. The mean $\mathrm{Cr}$ levels of the test water samples ranged from a minimum of $0.07 \mathrm{mg} / \mathrm{L}$ (sea water) to a maximum of $0.12 \mathrm{mg} / \mathrm{L}$ (borehole) (Fig. 3). The levels of $\mathrm{Cr}$ in the test water samples showed higher variations compared to their controls. However, analysis of variance showed no significant differences $(p>$ 0.05 ) between the main test water and their respective controls.

Similarly, sea water recorded the highest value $(64.54$ $\mathrm{mg} / \mathrm{L})$ of $\mathrm{Fe}$ with the least $(0.31 \mathrm{mg} / \mathrm{L})$ recorded in the borehole (Fig. 4). There were however no significant differences in $\mathrm{Fe}$ among the water sources.

The higher levels of heavy metals recorded in the main test water may be attributed to anthropogenic activities as heavy metals may be associated with oil and gas activities. Also, Iron with a permissible level of $10 \mathrm{mg} / \mathrm{l}$ had a mean value far above that of the control sample. Organic substances which form a major part of crude oil and petroleum products may to a large extent increase the heavy metal concentration upon release into water bodies. Meanwhile, smaller amounts of heavy metals such as lead $(\mathrm{Pb})$, Cadmium (Cd), Mercury $(\mathrm{Hg})$, Chromium (Cr), Cobalt (Co), Iron ( $\mathrm{Fe}$ ) and Copper (Co) above recommended levels are known to affect humans and the aquatic ecosystem (Ademoroti, 1996). According to Adesiyan et al. (2018), traces of heavy metals such as $\mathrm{Cr}, \mathrm{Pb}, \mathrm{Fe}$, and $\mathrm{Hg}$ above stipulated levels are toxic to aquatic ecosystems and human well-being. Amoasah (2010) also revealed that produced water for ocean discharge contains up to 48 parts per million $(\mathrm{ppm})$ of petroleum because it 
Ofosu, F. et al. / J. Appl. \& Nat. Sci. 13(2), 520 - 529 (2021)

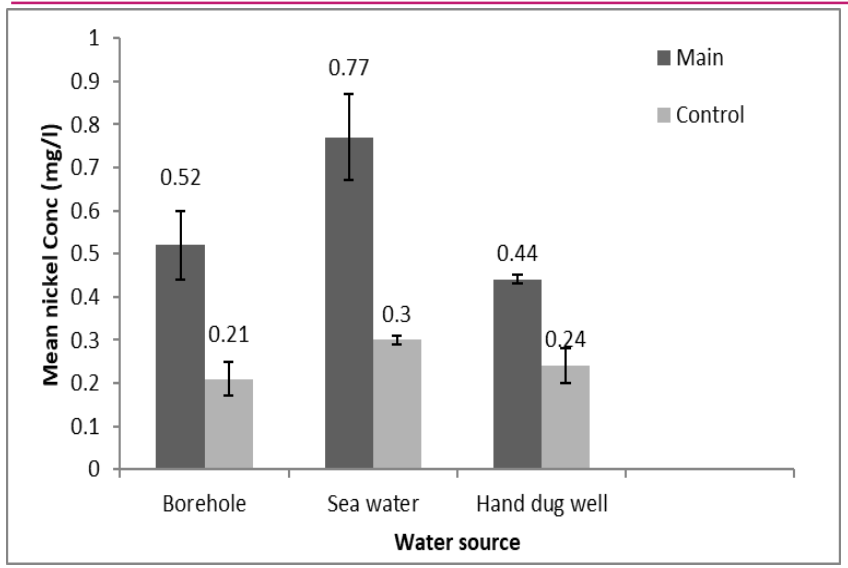

Fig. 2. Mean Nickel levels of water samples from Western Coast of Ghana.

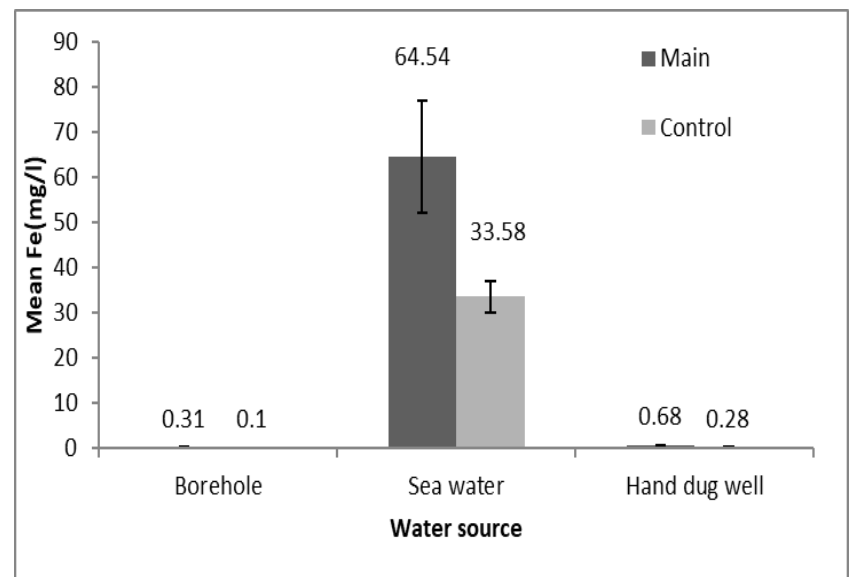

Fig. 4. Mean Iron levels of water samples from Western Coast of Ghana.

usually has contact with crude oil in the reservoir rocks. All water samples were within the permissible limit of guideline values of (WHO, 2011) except for sea water.

\section{Heavy metals concentration in fish samples}

All heavy metals ( $\mathrm{Pb}, \mathrm{Ni}$ and $\mathrm{Fe}$ ) analyzed in the two species (Pomatomus saltatrix and Cynoscion regalis) were present at varying concentrations except for $\mathrm{Cd}$ and $\mathrm{Cr}$ that were not detected. Generally, heavy metal concentration in Cynoscion regalis was higher than in Pomatomus saltatrix for all metals detected. The mean concentration $(\mathrm{mg} / \mathrm{kg}$ ) of $\mathrm{Pb}, \mathrm{Ni}$ and $\mathrm{Fe}$ in Pomatomus saltatrix fish were $1.86 \pm 0.19,1.95 \pm 0.25$ and $132.82 \pm$ $4.31(\mathrm{mg} / \mathrm{kg})$ respectively while those in Cynoscion regalis species were $2.44 \pm 0.13,3.13 \pm 0.12$ and 200.26 \pm 5.77 respectively (Table 2 ). Student t-test statistics showed significant differences $(p<0.05)$ in concentrations of heavy metals between the two fish species (Table 3).

The higher mean values of heavy metals in the fish could indicate prevalence from the sampling sites. The concentration of $\mathrm{Pb}$ in fish samples in this study is higher than the one reported by Maurya, et al.

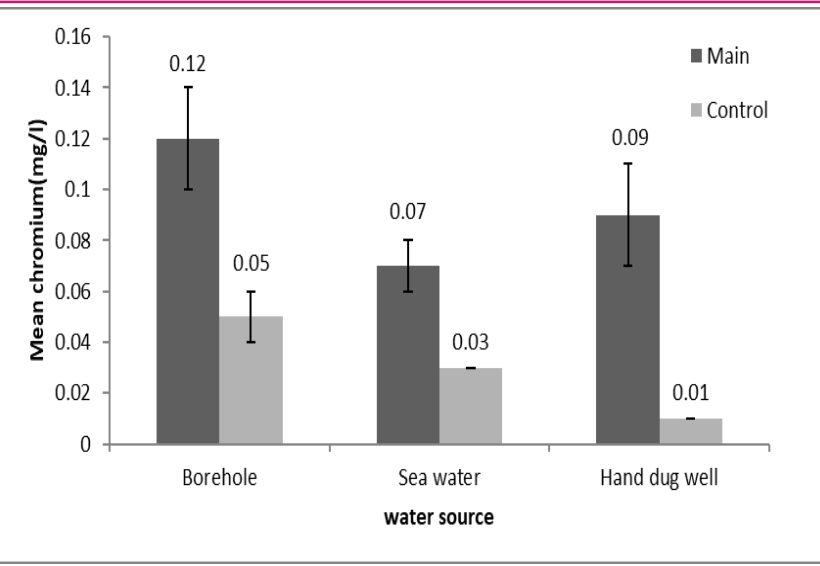

Fig. 3. Mean Chromium levels of water samples from Western Coast of Ghana.

(2019) in the River Ganga basin but lower than the concentration reported by Kortei et al. (2020) from Ankobrah and Pra basins in Ghana. According to Burger et al. (2002), there are two main routes of heavy metals exposure in fish species. The primary route of intake of these metals is through the gills or transport of dissolved contaminants in water across biological membranes and ionic exchange. The secondary route is through ingestion of food or sediment particles with subsequent transport across the gut. The aquatic micro flora or micro fauna which constitutes the food chain for fish species accumulate these metals in their living cells from the environment and as fish consume them they bio-accumulate these heavy metals which may subsequently affect humans in the food chain. These metals are known to produce adverse effects on aquatic biota and human health (Akan et al., 2012). Yang et al. (2010) reported that fish is very sensitive to $\mathrm{Pb}$ and its uptake increases with increasing concentration in the environment. Abarshi et al. (2017) reported that a fish living in contaminated sediment accumulates higher concentrations of $\mathrm{Pb}$ in gills and muscles, which is in line with this finding. The increase in contamination of metals in fish may be due to metalcontaminated diet, which may come from the discharge of oil residue and produced water that contains high levels of heavy metals (Owamah, 2013). The concentration of the heavy metals in the fish species increased in the order of $\mathrm{Pb}<\mathrm{Ni}<\mathrm{Fe}$.

\section{Health risk assessment}

Fish consumption has many health benefits; however, consuming toxic contaminated fish can have detrimental health effects on humans.

The calculated EDI, HQ, THQ for adults and children are presented in Table 5. For EDI the value for adults ranged from $1.88 \times 10^{-3}$ to $2.03 \times 10^{-1}(\mathrm{mg} / \mathrm{kg} \mathrm{bw} /$ day $)$ while that for children ranged from $4.40 \times 10^{-3}$ to $4.74 \mathrm{x}$ $10^{-1}(\mathrm{mg} / \mathrm{kg} \mathrm{bw} / \mathrm{day})$. Similarly, the hazard Quotient val- 
Table 1. Physico-chemical parameters of water sampled from the West coast of Ghana.

\begin{tabular}{llllllll}
\hline $\begin{array}{l}\text { Water } \\
\text { source }\end{array}$ & $\mathrm{pH}$ & $\begin{array}{l}\mathrm{EC} \\
(\mu \mathrm{S} / \mathrm{cm})\end{array}$ & $\begin{array}{l}\text { BOD } \\
(\mathrm{mg} / \mathrm{L})\end{array}$ & $\begin{array}{l}\text { DO } \\
(\mathrm{mg} / \mathrm{L})\end{array}$ & $\begin{array}{l}\text { Salinity } \\
(\mathrm{ppt})\end{array}$ & $\begin{array}{l}\text { TDS } \\
(\mathrm{mg} / \mathrm{L})\end{array}$ & $\begin{array}{l}\text { Turbidity } \\
(\mathrm{NTU})\end{array}$ \\
\hline $\begin{array}{l}\text { Borehole } \\
\text { main test }\end{array}$ & $6.1 \pm 0.35^{\mathrm{a}}$ & $246.8 \pm 88.9^{\mathrm{a}}$ & $6.08 \pm 0.35^{\mathrm{a}}$ & $10.37 \pm 0.31^{\mathrm{a}}$ & $0.008 \pm 0.04^{\mathrm{a}}$ & $161.0 \pm 57.58^{\mathrm{a}}$ & $0.64 \pm 0.11^{\mathrm{a}}$ \\
$\begin{array}{l}\text { Sea water } \\
\text { main test }\end{array}$ & $7.6 \pm 0.24^{\mathrm{b}}$ & $4618.9 \pm 673.0^{\mathrm{b}}$ & $4.31 \pm 0.20^{\mathrm{b}}$ & $8.42 \pm 0.76^{\mathrm{a}}$ & $29.9 \pm 5.02^{\mathrm{b}}$ & $2766.7 \pm 400.67^{\mathrm{b}}$ & $12.1 \pm 3.15^{\mathrm{a}}$ \\
$\begin{array}{l}\text { Hand dug } \\
\text { well main test }\end{array}$ & $6.8 \pm 0.19^{\mathrm{a}}$ & $623 \pm 107.5^{\mathrm{a}}$ & $4.14 \pm 0.48^{\mathrm{a}}$ & $8.29 \pm 0.72^{\mathrm{a}}$ & $0.30 \pm 0.06^{\mathrm{c}}$ & $399.7 \pm 67.53^{\mathrm{c}}$ & $0.87 \pm 0.35^{\mathrm{a}}$ \\
$\begin{array}{l}\text { Control } \\
\text { Borehole }\end{array}$ & $7.3 \pm 0.15^{\mathrm{a}}$ & $133.3 \pm 536^{6 \mathrm{a}}$ & $4.55 \pm 0.78^{\mathrm{a}}$ & $13.4 \pm 1.88^{\mathrm{a}}$ & $0.01 \pm 0.00^{\mathrm{a}}$ & $67.7 \pm 26.43^{\mathrm{d}}$ & $0.10 \pm 0.09^{\mathrm{a}}$ \\
$\begin{array}{l}\text { Control Sea } \\
\text { water }\end{array}$ & $8.0 \pm 0.20^{\mathrm{b}}$ & $2900 \pm 520.0^{\mathrm{a}}$ & $1.80 \pm 0.43^{\mathrm{c}}$ & $10.00 \pm 0.21^{\mathrm{a}}$ & $29.2 \pm 6.80^{\mathrm{b}}$ & $1440.0 \pm 160.00^{\mathrm{e}}$ & $10.20 \pm 7.78^{\mathrm{a}}$ \\
$\begin{array}{l}\text { Control Hand } \\
\text { dug well }\end{array}$ & $7.6 \pm 0.21^{\mathrm{b}}$ & $350 \pm 70.0^{\mathrm{a}}$ & $2.73 \pm 0.35^{\mathrm{b}}$ & $11.6 \pm 2.37^{\mathrm{a}}$ & $0.24 \pm 0.01^{\mathrm{a}}$ & $170.0 \pm 30.00^{\mathrm{a}}$ & $0.22 \pm 0.04^{\mathrm{a}}$ \\
\hline
\end{tabular}

Data on the same row with different superscript $(\mathrm{a}, \mathrm{b}, \mathrm{c}$,$) are significantly different at p<0.05$

Table 2. Concentrations of heavy metals in $P$. saltatrix and $C$. regalis species from the study area.

\begin{tabular}{lllll}
\hline $\begin{array}{l}\text { Heavy metals } \\
(\mathrm{mg} / \mathrm{kg})\end{array}$ & Fish species & Mean \pm SD & Min. & Max. \\
\hline \multirow{2}{*}{ Lead } & Pomatomus saltatrix & $1.86 \pm 0.19$ & 1.54 & 2.22 \\
& Cynoscion regalis & $2.44 \pm 0.13$ & 2.18 & 2.62 \\
\hline Cadmium & Pomatomus saltatrix & ND & 0.00 & 0.00 \\
& Cynoscion regalis & ND & 0.00 & 0.00 \\
\hline \multirow{2}{*}{ Chromium } & Pomatomus saltatrix & ND & 0.00 & 0.00 \\
& Cynoscion regalis & $1.95 \pm 0.25$ & 0.00 & 0.00 \\
\hline \multirow{2}{*}{ Nickel } & Pomatomus saltatrix & $3.13 \pm 0.12$ & 1.45 & 2.24 \\
\hline \multirow{2}{*}{ Iron } & Cynoscion regalis & $132.82 \pm 4.31$ & 124.50 & 138 \\
& Pomatomus saltatrix & $200.26 \pm 5.77$ & 190.00 & 210.00 \\
\hline
\end{tabular}

ND $=$ Not Detected

Table 3. Student $\mathrm{t}$ - test analysis of heavy metals in $P$. saltatrix and $C$. regalis fish samples from the Western Coast of Ghana.

\begin{tabular}{llllllcr}
\hline & t-value & df & p-value & $\begin{array}{l}\text { Mean } \\
\text { difference }\end{array}$ & & \multicolumn{2}{c}{$95 \%$ Confidence level } \\
\cline { 6 - 8 } Lead & 6.854 & 5 & $0.001^{*}$ & 1.15000 & 0.72 & Upper \\
Nickel & 5.260 & 5 & $0.003^{*}$ & 1.54333 & 0.79 & 2.29 \\
Iron & 10.734 & 5 & $0.000^{*}$ & 165.5433 & 125.89 & 205.19 \\
\hline
\end{tabular}

*Significant $(P \leq 0.05)$.

ue for adults ranged from 0.099 to 0.537 , while that for children ranged from 0.231 to 1.649 . The Target Hazard Quotient values for adults ranged from 0.036 to 0.258 while values for children ranged from 0.084 to 0.864 . The calculated value for Total Targeted Hazard Quotient (TTHQ) for adults who consume these fish species were less than $1(<1)$ (Table 3 ) however, those for children were greater than $1(>1)$ for Cynoscion regalis fish species but less than $1(<1)$ for Pomatomus saltatrix species (Table 4). The TTHQ values (2.307) for children increases even much higher if they consume both fish species. Exposure to high concentrations of $\mathrm{Pb}, \mathrm{Ni}$ and $\mathrm{Cr}$ are reported to cause central nervous system disorders, cardiovascular diseases, kidney failure, lung fibrosis, fertility problems, sinus node dysfunction, and atrioventricular conduction disturbances (Renieri et al., 2019; WHO, 2019 and Wani et al., 2015). Similarly, high concentrations of $\mathrm{Hg}$ in human is reported to cause kidney disease, liver failure, and memory loss (WHO, 2017). Similarly, Ho-Wang \& Wenxia (2020) reported that Fe toxicity causes Liver necrosis, Myocardial dysfunction and Cardiogenic shock among others.

\section{Conclusion}

This study assessed heavy metal concentrations in water and two fish species from the western coast of Ghana. Results showed appreciable concentrations of $\mathrm{Pb}, \mathrm{Ni}$, and $\mathrm{Cr}$ in the water samples. A high amount of $\mathrm{Pb}$ was detected in the muscles of $P$. saltatrix and $C$. regalis. The concentration of heavy metals in the fish species increased in the order $\mathrm{Pb}<\mathrm{Ni}<\mathrm{Fe}$. The EDI value for adult humans ranged from $1.88 \times 10^{-3}$ to 2.03 
Ofosu, F. et al. / J. Appl. \& Nat. Sci. 13(2), 520 - 529 (2021)

Table 4. Hazard Quotients and Target Hazard Quotients for Heavy Metals of $P$. saltatrix and C. regalis species from the Western Coast of Ghana.

\begin{tabular}{llllll}
\hline \multirow{2}{*}{ Metals } & Fish species & $\begin{array}{l}\text { EDI(adults) } \\
(\mathbf{m g} / \mathbf{k g ~ b w / d a y )}\end{array}$ & $\begin{array}{l}\text { EDI(chn) } \\
(\mathbf{m g} / \mathbf{k g} \text { bw/day) }\end{array}$ & $\begin{array}{l}\text { HQ } \\
\text { (adults) }\end{array}$ & $\begin{array}{l}\text { HQ } \\
\text { (Chn) }\end{array}$ \\
\hline \multirow{2}{*}{ Lead } & Pomatomus saltatrix & $1.88 \times 10^{-3}$ & $4.40 \times 10^{-3}$ & 0.537 & 1.257 \\
& Cynoscion regalis & $2.47 \times 10^{-3}$ & $5.77 \times 10^{-3}$ & 0.706 & 1.649 \\
\hline Cadmium & Pomatomus saltatrix & - & - & - & - \\
& Cynoscion regalis & - & - & - & - \\
\hline Chromium & Pomatomus saltatrix & - & - & - & - \\
& Cynoscion regalis & - & - & - & - \\
\hline \multirow{2}{*}{ Nickel } & Pomatomus saltatrix & $1.98 \times 10^{-3}$ & $4.62 \times 10^{-3}$ & 0.099 & 0.231 \\
& Cynoscion regalis & $3.17 \times 10^{-3}$ & $7.41 \times 10^{-3}$ & 0.158 & 0.371 \\
\hline \multirow{2}{*}{ Iron } & Pomatomus saltatrix & $1.34 \times 10^{-1}$ & $3.12 \times 10^{-1}$ & 0.191 & 0.445 \\
& Cynoscion regalis & $2.03 \times 10^{-1}$ & $4.74 \times 10^{-1}$ & 0.290 & 0.677 \\
\hline Total & & $3.47 \times 10^{-1}$ & $8.1 \times 10^{-1}$ & 1.981 & 4.630 \\
\hline
\end{tabular}

$\Sigma \mathrm{HQs}=\mathrm{HI}, \mathrm{HI}_{\text {adults }}=1.981 ; \quad \mathrm{HI}_{\mathrm{chn}}=4.630$

Table 5. Estimated Total Target Hazard Quotient (TTHQ) of $P$. saltatrix and $C$. regalis fish species from the Western Coast of Ghana.

\begin{tabular}{lcc}
\hline Fish species & Population & TTHQ \\
\hline $\begin{array}{l}\text { Pomatomus } \\
\text { saltatrix }\end{array}$ & Adult & 0.303 \\
$\begin{array}{l}\text { Pomatomus } \\
\text { saltatrix }\end{array}$ & Children & 0.706 \\
$\begin{array}{l}\text { Cynoscion } \\
\text { regalis } \\
\begin{array}{l}\text { Cynoscion } \\
\text { regalis }\end{array}\end{array}$ & Adult & 0.422 \\
\hline
\end{tabular}

Total target hazard quotients for both fish species for adults $\left(T T H Q_{\text {adults }}\right)=0.725$

Total target hazard quotients for both fish species for children $\left(T T H Q_{c h n}\right)=2.307$

$x 10^{-1}(\mathrm{mg} / \mathrm{kg}$ bw/day) while that for children ranged from $4.40 \times 10^{-3}$ to $4.74 \times 10^{-1}(\mathrm{mg} / \mathrm{kg}$ bw/day). Health risk assessment showed that the TTHQ for adult was less than $1(<1)$ however those for children were greater than $1(>1)$ for $C$. regalis species but less than $1(<$ 1) for $P$. saltatrix species which means that children who eat these fishes are exposed to health risk in their lifetime. The general public's awareness and education on the threshold of heavy metals in fish and water are crucial to safeguard human health.

\section{ACKNOWLEDGEMENTS}

The authors wish to express their profound gratitude the Fisheries Commission's department in the Western Region especially Miss Josephine Laryea for her support during data collection. Our profound gratitude also goes to Mr. Anthony Afful, Mr. Emmanuel Bonyah, Mr. Bright Frimpong, Mason A. Koranteng and Alvin AduAsare for their contributions towards this work.

\section{Conflict of interest}

The authors declare that they have no conflict of interest.

\section{REFERENCES}

1. Abarshi, M. M., Abubakar, A. L., Garba, A., Mada, S. B., Ibrahim, A. B. \& Maruthi, M. N. (2017). Molecular detection and characterisation of Horsegram Yellow Mosaic Virus (HgYMV) infecting Lima bean (Phaseolus lunatus) in India. Nig J. Biotech., 33: 41-48

2. Abdel-Shafy, H. I. \& Mansour, M. S. M. (2016). A review on polycyclic aromatic hydrocarbons: sources, environmental impact, effect on human on health and remediation. Egyptian Journal of Petroleum, 25, 107-123.

3. Ademoroti, C. M. O. (1996). Standard methods for water and effluents analysis. Foludex Press Ltd., Ibadan. 3: 29118.

4. Adesiyan, M. I., Bisi-Johnson, M., Aladesanmi, O. T., Okoh, A. I. \& Ogunfowokan , A. O. (2018). Concentrations and Human Health Risk of Heavy Metals in Rivers in Southwest Nigeria. Journal of Health \& Pollution 8 (19), 114.

5. Akan, J. C., Mohmoud, S., Yikala, B. S., \& Ogugbuaja, V. O. (2012). Bioaccumulation of some heavy metals in fish samples from river Benue in Vinikilang, Adamawa State Nigeria. American Journal of Analytical Chemistry, 03(11), 727-736.

6. Amfo-Otu R, Omari S, \& Boakye-Dede, E. (2012). Assessment of Physico-chemical Quality of Groundwater Sources in Ga East Municipality of Ghana, Environment and Natural Resources Research, 2(3), 19-24. http:// doi.org/10.5539/enrr.v2n3p19

7. Amoasah, G. (2010). The potential impacts of oil and gas exploration and production on the coastal zone of Ghana: An ecosystem services approach. MSc Thesis submitted to Wageningen University. Page $1-76$.

8. Apau, J., Acheampong, A., Bepule, V. (2014). Physicochemical and Microbial Parameters of Water From Hand- 
Dug Wells From Nyamebekyere , A Surburb of Obuasi , Ghana. International Journal of Science and Technology, 3(6), 347-351.

9. Appiah Opong, R., · Amoako, O., Ofosuhene, M., Ofori Attah, E · Nunoo, F. K. E. Tuffour, I., Gordon, C., Arhinful, D. K., Nyarko, A. K., Fosu Mensah, B. Y (2021). Applied Water Science 11(57). https://doi.org/10.1007/ s13201-021-01386-5.

10. Armah, A., Biney, C., Dahl, S., \& Povlsen, E. (2004). Environmental sensitivity map for coastal areas of Ghana. EPA/UNDP Report, vol. 2.

11. Barmon, P. C. Islam, M. S. \& Kabir, M. H. (2018). Physicochemical Parameters and Heavy Metal Concentration in Water at the Mokesh Beel of Bangladesh. J. Environ. Sci. \& Natural Resources, 11 (1\&2): 1-8.

12. Burger, J., Gaines, K. F., Boring, C. S., Stephens, W. L. Jr., Snodgrass, J., Dixon, C., McMahon, M., Shukla, S., Shukla, T. \& Gochfeld, M. (2002). 'Metal levels in fish from the Savannah River: Potential hazards to fish and other receptors', Environ. Res. 89, 85-87.

13. Chiamsathit, C., Supunnika, A. \& Thammarakcharoen, S. (2020). Heavy metal pollution index for assessment of seasonal groundwater supply quality in hillside area Kalasin, Thailand. Applied Water Science 10:142 https:// doi.org/10.1007/s13201-020-01230-2

14. Demeke, A., \& Tassew, A. (2016). A review on water quality and its impact on Fish health. International Journal of Fauna and Biological Studies, 3, 21-31.

15. Demková, L., Jezný, T. \& Bobul'ská, L. (2017). Assessment of soil heavy metal pollution in a former mining area - before and after the end of mining activities. Soil \& Water Res., 12, 229-236.

16. E \&P Forum/UNEP (1997). Environmental management in oil and gas exploration and production. An overview of issues and management approaches. Joint $E$ and $P$ Forum/UNEP Technical Publication 37. Oxford. UK.

17. Faz, M. A. \& Acosta, J. A (2017) Effect of different industrial activities on heavy metal concentrations and chemical distribution in topsoil and road dust. Environ Earth Sci 76, 129 (2017). https://doi.org/10.1007/s12665-017-6449-4

18. Ghaderpoori, M., Najafpoor, A. A., Ghaderpoury, A., \& Shams, M. (2018). Data on floride concentration and health risk assessment of drinking water in Khorasan Razavi provice, Iran. Data in Brief18 1596-1601.

19. Global Muckraking, (2012). West Africa oil boom overlooks tattered environmental safety net. Accra.https:// publicintegrity.org/accountability/west-africa-oil-boomoverlooks-tattered-environmental-safety-net.

20. GNPC (2009), Exploration and production history of Ghana. http://www.gnpcghana.com.

21. Griboff, J., Wunderlin, D. A. \& Monferran, M. V. (2017) Metals, As and Se determination by inductively coupled plasma-mass spectrometry (ICP-MS) in edible fish collected from three eutrophic reservoirs. Their consumption represents a risk for human health? Microchem J., 130, 236-24.

22. Ho-Wang,Y. \& Wenxia, B. (2020). Iron Toxicity. StatPearls Publishing LLC. NBK 459224 PMID: 29083637. https:// www.ncbi.nlm.nih.gov/books/NBK459224/

23. Igwe, O. C., Saadi, A. A. L., \& Ngene, S. E. (2013). Optimal options for treatment of produced water in offshore petroleum platform. J. Pollut. Eff. Cont., 1,1. DOI:
10.4172/2375-4397.1000102

24. Kadafa, A. A. (2012). Oil exploration and spillage in the Niger delta of Nigeria. Civil and Environmental Research $2,38-51$.

25. Katavut P., Wattanakornsiri A. \& Jakkaphun, N. (2010). Heavy metal transport and fate in the environmental compartments. NU Science Journal, 7(1), 1-11.

26. Kinuthia, G.K., Ngure, V., Beti, D. Lugalia, R., Wangila, A. \& Kamau, L. (2020). Levels of heavy metals in wastewater and soil samples from open drainage channels in Nairobi, Kenya: community health implication. Sci. Rep., 10, 8434 . https://doi.org/10.1038/s41598-020-65359-5

27. Kortei, N. K., Heymann, M. E., Essuman, E. K., Kpodo, F. M., Akonor, P. T., Lokpo, S. Y., Boadi, N. O., Ayim-Akonor M. \& Tettey C. (2020). Health risk assessment and levels of toxic metals in fishes (Oreochromisnoliticus and Clariasanguillaris) from Ankobrah and Pra basins: Impact of illegal mining activities on food safety. Toxicology Reports 7: $360-369$

28. Kwaansa-Ansah, E. E., Nti, S. O., \& Opoku, F. (2019). Heavy metals concentration and human health risk assessment in seven commercial fish species from Asafo Market, Ghana. Food Sci. Biotechnol., 28(2), 569-579.

29. Lloyd R. (1992): Pollution and freshwater fish. Fishing News Books, Oxford, UK, pp. 192.

30. Mallya, Y. J. (2007). The effects of dissolved oxygen on fish growth in aquaculture. UNU-Fisheries Training Programme. Page 1 - 30

31. Maurya, P. K., Malika, D.S., Yadavb, K. K., Kumarc, A., Kumard, S. \&Kamyabe, H. (2019). Bioaccumulation and potential sources of heavy metal contamination in fish species in River Ganga basin: Possible human health risks evaluation. Toxicology Reports, 6, 472-481.

32. Noor-ul, A., \& Tauseef, A. (2015). Contamination of soil with heavy metals from industrial effluent and their translocation in green vegetables of Peshawar, Pakistan. J. RSC Advances, 19, 14322-14329.

33. Owamah, H. I. (2013). Heavy Metals Determination and Assessment in a Petroleum Impacted River in the Niger Delta Region of Nigeria. J. Pet. Environ. Biotechnol., 4, 135. doi:10.4172/2157-7463.1000135.

34. Rai, P. K., Leeb, S. S., Zhang, M., Tsang, Y. F., \& KiHyun, K. (2019). Heavy metals in food crops: Health risks, fate, mechanisms, and management. Environment International, 125, 365-385.

35. Renieri, E. A., Safenkova, I.V., Alegakis, A.K. Slutskaya, E.S., Kokaraki, V., Kentouri, M., Dzantiev, B.B., Tsatsakis, A. M. (2019). Cadmium, lead and mercury in muscle tissue of gilthead seabream and seabass: risk evaluation for consumers, Food Chem. Toxicol., 124, 439-449.

36. Rodier, J., Legube, B., Merlet, N. (2009). The Analysis of Water, 9th ed.; Editions Dunod: Paris, France, 1- 5.

37. Shirazu, I., Mensah, Y. B., Schandorf, C. \&Mensah, S. Y. (2017). Determination of Standard Reference Body Indices for Clinical Application in Ghana. International Journal of Scientific \& Technology Research, 6 (2), 225-231.

38. Ubiogoro, O.E and Adeyemo, O.K. (2017). Heavy metal pollution of aquatic systems in oil producing communities of delta state, Nigeria. J. Appl. Biosci., 120, 11993-11998.

39. USDA (2019). Global Agricultural Information Network: Ghana Fish and Seafood Report

40. Vrhovnik, P, Smuc, N. R, Dolenec, T., Serafimovski, T., 
Dolenec, M. (2013). An evaluation of trace metal distribution and environmental risk in sediments from the Lake Kalimanci (FYR Macedonia). Environ. Earth Sci., 70, 761775 .

41. Wani, A.L.; Ara, A.; Usmani, J.A. (2015). Lead toxicity: A review. Int. Toxicol. 2015, 8, 55-64

42. World Health Organization (2011) Guidelines for drinkingwater quality. World Health Organization, Geneva.

43. WHO (2020). Global Health Observatory. https:// www.who.int/countries/gha/en/

44. World Health Organization (2019). Lead poisoning and health, cited on $13^{\text {th }}$ April 2021. https://www.who.int/news- room/fact-sheets/detail/lead-poisoning-and-health

45. World Health Organization (2017). Mercury and health. Cited $13^{\text {th }}$ April $2021 \mathrm{https}: / / w w w . w h o . i n t / n e w s-r o o m / f a c t-$ sheets/detail/mercury-and-health

46. Yang, X., Xiong, B. \&Yang, M. (2010). Relationships among heavy metals and organic matter in sediment cores from Lake Nanhu, an Urban Lake in Wuhan, China. J. Freshw. Ecol., 25:243-249.

47. Yi, Y., Tang, C., Yi, T., Yang, Z., \& Zhang, S. (2017) Health risk assessment of heavy metals in fish and accumulation patterns in food web in the upper Yangtze River, China. Ecotoxicology and Environmental Safety, 145, 295-302. 